\title{
PAPER
}

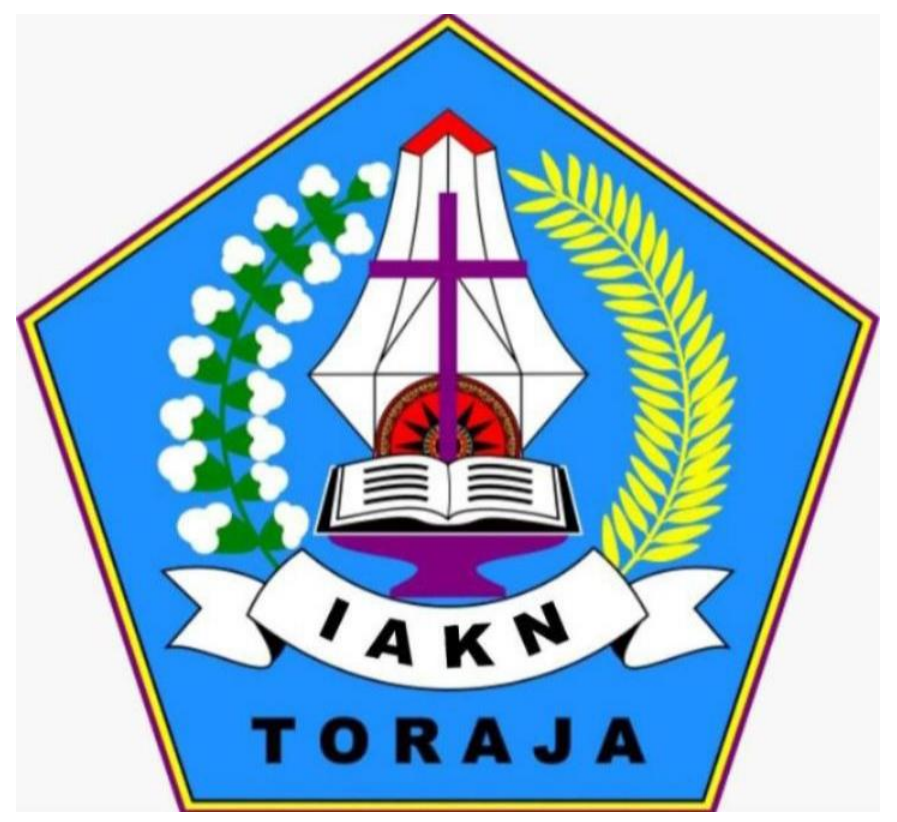

NAMA : JUWITA PANDUNG

KELAS : A. TEOLOGI

NIRM : 2020196374 


\section{JABATAN DALAM GEREJA, MENURUT STRATA SOSIAL?}

\section{Abstrak : berisi garis besar ringkasan makalah/paper}

Paper ini membahas tentang bagaimana suatu jabatan dalam gereja, apakah jabatan itu diberikan menurut strata sosial atau jabatan yang di berikan sesuai dengan kemampuan. Saya menulis paper ini berdasarkan hasil riset dari beberapa jurnal. Paper ini bertujuan untuk menunjukkan / membangun kesadaran gereja dalam memberikan jabatan kepada jemaat.

\section{Pendahuluan}

Jabatan merupakan suatu kedudukan yang menunjukkan tugas, fungsi, tanggung jawab, wewenang dan hak seseorang dalam suatu jabatan tersebut. Kita dapat menjumpai berbagai macam jabatan dalam masyarakat. Contohnya : pemangku adat, Lurah dan tak terpungkiri dalam suatu gereja pun memiliki jabatan. Jabatan dalam masyarakat biasanya di pengaruhi oleh strata sosial, dan dalam budaya Toraja untuk mendapatkan / memberikan suatu jabatan biasanya kita berkaca dari strata sosial (bangsawan). Pertanyaannya, apakah suatu jabatan gereja juga berkaca dari strata sosial tersebut?

\section{Tujuan dan manfaat}

Tujuan dari paper ini adalah menunjukkan / membangun kesadaran gereja (orangnya), dalam memberikan suatu jabatan kepada jemaat. Paper ini kiranya dapat memberi manfaat kepada gereja dalam memberikan suatu jabatan dengan melihat kemampuan yang ada.

\section{Pembahasan}

Kepemimpinan dalam kaca mata masyarakat Toraja tradisionil sangat berkaitan erat dengan "startifikasi sosial" (tana'). Adapun yang dapat dicermati dalam kepemimpinan tradisional berbasis stratifikasi sosial (tana') adalah telah tertentunya batas yuridiksi kepemimpinannya. Dengan kata lain kepemimpinan turut ditentukan oleh wilayah adat yang telah digariskan oleh tongkonan pesio'aluk. Adapun yang dapat dicermati dalam kepemimpinan tradisional berbasis stratifikasi sosial (tana') adalah telah tertentunya batas yuridiksi kepemimpinannya. Dengan kata lain kepemimpinan turut ditentukan oleh wilayah adat yang telah digariskan oleh tongkonan pesio'aluk. ${ }^{1}$

\footnotetext{
${ }^{1}$ Rannu Sanderan, "STRATIFIKASI SOSIAL Kepemimpinan Tradisional Dalam Dinamika Demokrasi Modern", 1
} 
Kepemimpinan tradisional berdasarkan garis keturunan atau stratifikasi sosial (tana') yang diwarisi dari tongkonan dimana yang bersangkutan terlahir atau menjadi keturunan. Jadi ada muatan hierarkhi dalam konsep kepemimpinan tradisional berbasis stratifikasi sosial tongkonan (tana'). Umumnya, kategori tongkonan yang dapat menjadi pemimpin atau penguasa adalah tongkonan pekaindoran atau pekaamberan yang lazim dikenal dengan nama tongkonan kaparengngesan, tongkonan kabarasan, tongkonan anak to patalo yaitu tongkonan yang didirikan oleh penguasa-penguasa dalam masing-masing daerah untuk mengatur pemerintahan adat berdasarkan aturan dari tongonan pesio'aluk. ${ }^{2}$

Kemudian, pengangkatan suatu jabatan dalam masyarakat Toraja khususnya yang menyangkut jabatan-jabatan pemerintahan, adat, (bahkan masa kini dalam jabatan gerejawi) umumnya didasarkan pada nilai tana'. Artinya, yang berhak menduduki jabatan pemerintahan, adat adalah golongan dari "bangsawan", walaupun terdapat orang lain dari golongan rendah yang lebih mampu. Kemudian, persoalan ini secara sosial akhirnya ikut merambat masuk ke dalam gereja atau jemaat, sehingga kadangkala pengangkatan pejabatpejabat (pemimpin) gereja turut dipengaruhi oleh tana', dan tanpa disadari melahirkan praktik feodalisme sempit, bahkan tidak jarang ada kecenderungan pada monarkhi absolut, parahnya hal ini mendapat kredensi sosial. ${ }^{3}$

Pengaruh stratifikasi sosial dalam memilih dan menetapkan pemimpin dalam gereja masih ada, karena seorang pemimpin hendaknya berani, kaya, pintar dan seorang bangsawan. Dengan kata lain golongan bangsawan, mendapat perioritas utama dipilih atau ditetapkan oleh sebagai pemimpin; kepemimpinan dalam bingkai seperti itu diidentikkan kekuasaan atau otoritas mutlak dari seorang bangsawan, termasuk merambat ke dalam hal memilih dan menetapkan pejabat gerejawi. Artinya ada wewenang mutlak bagi kaum bangsawan untuk menikmati gengsi dan hak untuk memerintah dalam bingkai kepemimpinan. ${ }^{4}$

\footnotetext{
${ }^{2}$ Rannu Sanderan, "STRATIFIKASI SOSIAL Kepemimpinan Tradisional Dalam Dinamika Demokrasi Modern", 1

${ }^{3}$ Rannu Sanderan, "STRATIFIKASI SOSIAL Kepemimpinan Tradisional Dalam Dinamika Demokrasi Modern", 2

${ }^{4}$ Rannu Sanderan, "STRATIFIKASI SOSIAL Kepemimpinan Tradisional Dalam Dinamika Demokrasi Modern", 7
} 
Peradaban manusia Toraja sudah ada jauh hari sebelum datangnya institusi sekolah. Mereka tumbuh dan berkembang secara tradisional, dengan norma dan tatanan sosial yang melahirkan entitas budaya serta identitasnya. Kehidupan dan budaya orang Toraja tersebut menggambarkan kualitas berpikir dan kualitas hidup. ${ }^{5}$

Masalah riset yakni entitas budaya serta identitasnya menjadi obyek yang memerlukan upaya pencarian secara ilmiah. Bagi khalayak orang Toraja, baik kelompok tradisional mapun kaum modernis, pencarian identitas mereka berkaitan langsung dengan teritori (kampung atau tondok). Pada pihak lain, ada sebagian besar lainnya yang meneguhkan jati dirinya bertumpu pada satu Klan yang berbasis pada satu Tongkonan. Jadi bagi sebagian orang Toraja, Tongkonan-lah yang menjadi pembobot atau penentu kapasitas individu. ${ }^{6}$

Hal ini juga dapat dipengaruhi dari budaya modernisme. Kita diindoktrinasi oleh lingkungan untuk menjadi makhluk-makhluk pemburu kesenangan yang tidak pernah terpuaskan. Berbagai cara dilakukan oleh manusia untuk mencari kepuasan bagi dirinya, keluarganya atau kelompoknya. Jika disimak dengan baik kriminalitas dan penyakit sosial yang semakin meningkat akhir-akhir ini pada umumnya disebabkan oleh keinginan untuk mencari kenikmatan. ${ }^{7}$

Karena itu kita membutuh pengendalian diri. Salah satu hal penting dalam dunia pendidikan yang sudah lama ditinggalkan dalam pendidikan formal adalah unsur asketik. Padahal dalam budaya maupun PAK unsur asketik berupa pengendalian diri, puasa atau berpantang jelas dan nyata ada bahkan diteladankan oleh Yesus sendiri. ${ }^{8}$ Dalam sejarah gereja, latihan askese untuk menahan diri, mengosongkan diri, bahkan menyiksa diri merupakan hal yang wajib bagi seorang hamba Tuhan. Kegiatan ini bukan tradisi yang muncul begitu saja, atas dasar pemahaman pribadi terhadap Alkitab, namun praktik askese memang terdapat dalam Alkitab dan diperintahkan oleh Firman Tuhan. ${ }^{9}$

\footnotetext{
${ }^{5}$ Rannu Sanderan, "Heuritika dalam Pendidikan Karakter Manusia Toraja Tradisional", Jurnal Teologi, Vol.3 N0.2 (Desember, 2020), 1

${ }^{6}$ Rannu Sanderan, "Heuritika dalam Pendidikan Karakter Manusia Toraja Tradisional”, Jurnal Teologi, Vol.3 N0.2 (Desember, 2020), 2

${ }^{7}$ Rannu Sanderan "Disiplin Asketisme dan Harmoni Kontribusi Disiplin Diri Bagi Pengembangan Pendidikan Kristen", 1

${ }^{8}$ Rannu Sanderan “Disiplin Asketisme dan Harmoni Kontribusi Disiplin Diri Bagi Pengembangan Pendidikan Kristen", 1

${ }^{9}$ Rannu Sanderan "Disiplin Asketisme dan Harmoni Kontribusi Disiplin Diri Bagi Pengembangan Pendidikan Kristen”, 11
} 
Pendidikan sebagai sebuah proses, kini ditantang untuk dapat menginternalisasi makna dan berbagai perubahan yang mendasar menyangkut orientasi cara pandang tersebut. Untuk itu, kini amat dibutuhkan adanya transformasi pendidikan. Sekarang, pendidikan sudah harus merujuk kepada adanya konsekwensi logis dan berbagai perubahan perilaku, sikap, dan tata budaya. Bila melihat ruang hidup keagamaan dewasa ini, ternyata tidak lagi berwajah tunggal, namun sudah bersifat multifaces (berwajah banyak). Dengan demikian, pendidikan yang berparadigma asketis dapat menjadi salah satu upaya transformasi alternatif menuju penumbuhan hikmat dan disiplin insani. ${ }^{10}$

Pendidikan yang berpola asketisme menjadikan manusia memiliki akal yang selanjutnya memampukan ia berpikir lebih panjang dalam membuat perencanaan dalam hidupnya. Pengendalian diri dalam menunda atau menolak sesuatu yang kurang bermanfaat untuk sesuatu yang lebih berguna dan membahagiakan memerlukan proses latihan melalui pendidikan disiplin kendali diri. ${ }^{11}$

Untuk belajar hal-hal memperbaiki cara pandang dalam memberikan suatu jabatan, tidak ada salahnya dimulai dari generasi muda. Contohnya dalam pendidikan iman. Iman lebih dominan diperoleh (dipelajari) justru melalui budaya; dan secara konkrit lebih banyak melalui keteladanan dan interelasi individual. Dengan kata lain, kepercayaan atau iman lebih dipengaruhi melalui pembentukan kultur. ${ }^{12}$

Lingkungan masyarakat yang baik (dalam konteks dominan) memegang teguh nilai-nilai dan norma-norma perilaku yang baik, sejatinya dapat menyokong kehidupan keluarga (Kristen) yang tinggal dalam suatu lingkungan secara baik pula. Perilaku manusia lebih banyak berfungsi karena dibentuk oleh pengamatan dan dipengaruhi oleh proses meniru perilaku orang lain. Anak-anak melihat bagaimana orangtuanya berperilaku selanjutnya meniru lanjut perilaku tersebut. ${ }^{13}$

\footnotetext{
${ }^{10}$ Rannu Sanderan "Disiplin Asketisme dan Harmoni Kontribusi Disiplin Diri Bagi Pengembangan Pendidikan Kristen", 7

${ }^{11}$ Rannu Sanderan "Disiplin Asketisme dan Harmoni Kontribusi Disiplin Diri Bagi Pengembangan Pendidikan Kristen", 10

${ }^{12}$ Rannu Sanderan, "EXEMPLARY, Menemukenali Kunci Pendidikan Kristen Bagi Anak dalam Keluarga dan Pembelajaran Agama di Sekolah", 1

${ }^{13}$ Rannu Sanderan, "EXEMPLARY, Menemukenali Kunci Pendidikan Kristen Bagi Anak dalam Keluarga dan Pembelajaran Agama di Sekolah", 2
} 
Pendidikan yang berpola asketisme menjadikan manusia memiliki akal yang selanjutnya memampukan ia berpikir lebih panjang dalam membuat perencanaan dalam hidupnya. Pengendalian diri dalam menunda atau menolak sesuatu yang kurang bermanfaat untuk sesuatu yang lebih berguna dan membahagiakan memerlukan proses latihan melalui pendidikan disiplin kendali diri. ${ }^{14}$

\section{Kesimpulan \& Saran}

Dalam memberikan suatu jabatan dalam gereja, kita harus melihat dari kemampuan serta tanggung jawab dalam mengemban tugas yang diberikan. Bukan memilih pejabat gereja dengan berkaca dari status sosial. karena tidak bisa dipungkiri banyak orang yang memiliki kemampuan dalam menduduki suatu jabatan dalam gereja, tetapi tidak adanya kekuatan status sosial sehingga orang-orang tersebut tidak diberi jabatan.

\footnotetext{
${ }^{14}$ Rannu Sanderan "Disiplin Asketisme dan Harmoni Kontribusi Disiplin Diri Bagi Pengembangan Pendidikan Kristen", 10
} 